УДК 35.076

DOI https://doi.org/10.32851/tnv-pub.2021.3.3

\title{
ДОСВІД РОЗВИТКУ СИСТЕМИ ЕЛЕКТРОННИХ ДЕРЖАВНИХ ПОСЛУГ У КРАЇНАХ ЄВРОПЕЙСЬКОГО СОЮЗУ
}

\author{
Величко Л.Ю. - доктор юридичних наук, професор, \\ завідувач кафедри права, національної безпеки та європейської інтеграції \\ Навчально-наукового інституту «Інститут державного управління» \\ Харківського національного університету імені В.Н. Каразіна \\ ORCID: 0000-0003-3029-4719
}

Васильковський О.T. - старший викладач кафедри соціально-гуманітарних дисциплін, підполковник Національної академії Національної гвардії України ORCID: 0000-0002-6456-7167

У статті розглянуто досвід розвитку системи електронних державних послуг у країнах Свропейського Союзу. 3'ясовано основні завдання системи електронних державних послуг, до яких належать: координація й адміністрування взаємодії між державними структурами; організація обслуговування громадян державними органами; організація взаємодії структур влади та бізнесу; видача громадянам будь-якої інформачії, пов'язаної з діяльністю державних органів; створення форм правління за участю громадян; забезпечення рівної доступності благ незалежно від місия проживання громадянина та ін. Визначено, шуо структура онлайнової системи електронних державних послуг і ї органів управління повинна містити у собі: інтернет - загальнодоступні сервери, які надають доступ до електронних державних послуг; безкоштовні контакт-цеентри, суміщені з мережею телефонні call-центти, котрі дозволяють надавати послуги для громадян, які не мають доступу в інтернет; поштову службу для посилки документів і матеріалів у письмовому вигляд $i$; інтранет для підвищення ефективності роботи державних службовців. Доведено, щуо існує чотири рівні зрілості електронних державних послуг: інформаційний офіси публікують інформачію на веб-сайті, а користувачі переглядають сайт офісів на комп 'ютері або спеціальних інформаційних кіосках, отримуючи необхідну інформацію; інтерактивний, в одну сторону - користувачі можуть спілкуватися в електронному вигляді з окремими офісами, двосторонній - де офіси можуть спілкуватися з користувачами через Інтернет; угоди - користувачі можуть спілкуватися в електронному вигляді з окремими офісами, а офісні додатки електронним иляхом їм відповідають; інтеграиії- портали призначені для певних иілей, надають інформацію з різних офісів і дозволяють здійснювати виконання угод. Досліджено етапи розвитку системи електронних державних послуг у країнах Свропейського Союзу, иілі та завдання кожного етапу, проблеми та рекомендації щзодо їх нівелювання.

Ключові слова: державне управління, послуги, сфера послуг, електронні державні послуги, класифікація послуг, цчифрова економіка.

Velychko L.Yu., Vasylkovskyi O.T. Experience in the development of the electronic public services system in the European Union countries

The article considers the experience of developing the electronic public services system in the European Union countries. The main tasks of the electronic public services system are clarified, which include: coordination and administration of interaction between state structures; Organization of services to citizens by state bodies; Organization of interaction between government and business structures; issuance of any information to citizens related to the activities of state bodies; creation of forms of government with the participation of citizens; ensuring equal availability of benefits, regardless of the place of residence of a citizen, etc. It is determined that the structure of the online system of electronic public services and its governing bodies should include: internet - public servers that provide access to electronic public services; free contact centers, combined with a network of telephone call centers that allow you to provide services for citizens who do not have internet access; a postal service for sending documents and materials in writing; an intranet to improve the efficiency of civil servants. It is proved that there are four levels of maturity of electronic public services - information-offices publish information on 
a website, and users view the site of offices on a computer or special information kiosks, receiving the necessary information; interactive, one - way - users can communicate electronically with individual offices, two - way-where offices can communicate with users via the Internet; agreements-users can communicate electronically with individual offices, and office applications electronically respond to them; integrations-portals are designed for specific purposes, provide information from different offices, and allow you to execute transactions. The article examines the stages of development of the electronic public services system in the European Union countries, the goals and objectives of each stage, problems and recommendations for their leveling.

Key words: public administration, services, service sector, electronic public services, classification of services, digital economy

Постановка проблеми. Поряд із координуючою (регулюючою), однією з найважливіших функцій держави є інформаційно-комунікаційна. Держава покликана забезпечувати економічні зв'язки та взаємодію всіх економічних агентів, структуруючи систему соціально-економічних відносин і надаючи цій системі цілісність і життєздатність. В умовах становлення цифрової економіки значення зазначеної функції держави кардинально зростає. Нові інформаційно-комунікативні технології не тільки створюють більш досконалі механізми збору, обробки, зберігання та передачі інформації, а й зумовлюють нові форми соціально-економічної взаємодії, у тому числі через мережеві електронні платформи.

Одним із напрямків процесів інформатизації є формування системи електронних державних послуг, на базі якої здійснюється взаємодія держави з населенням та організаціями у таких сферах, як надання інформації, у тому числі за приватними запитами, організація державних (муніципальних) закупівель, надання державних послуг, формування системи зворотного зв'язку (інститут скарг) та ін.

Сучасна держава повинна забезпечувати своїм громадянам і бізнес-організаціям контакти з установами та публічними адміністраціями на основі електронного доступу. Грамотно проведена інформатизація публічної адміністрації сприяє відкритості та прозорості державного сектору.

Аналіз останніх досліджень і публікацій. У науковій літературі приділяється увага дослідженню сутності й особливостям надання державних та адміністративних послуг. Їм присвячені роботи таких зарубіжних і вітчизняних дослідників, як А.О. Чемерис [1], М.Д. Лесечко [1], А.В. Ліпенцев [1], В.М. Сороко [9], А.В. Вишневський [9], О.Г. Рогожин [9], О.В. Берданова [8], В.М. Вакуленко [8], М.Д. Василенко [8], О.М. Петрова [7] та ін. Водночас із огляду на складність і багатогранність проблеми залишається ще багато теоретичних і практичних прогалин у їі вивченні. Зокрема, недостатньо досліджено економічні та соціально-політичні аспекти функціонування системи електронних державних послуг.

Метою статті $\epsilon$ узагальнення досвіду розвитку системи електронних державних послуг у країнах Свропейського Союзу.

Виклад основного матеріалу. Сучасний інтегрований підхід спрямований на формування концепції єдиного інформаційного порталу для реалізації системи електронних державних послуг.

Завдяки єдиній точці доступу до державних електронних послуг громадяни зможуть брати активну участь у суспільному житті та демократичних процесах, а бізнес ефективно розвивається.

Структура інформаційного порталу для реалізації системи електронних державних послуг повинна містити оперативну та довідкову інформацію про послуги та спосіб їх отримання. Користувач порталу повинен із задоволенням заходити на портал і легко знаходити відповідні дані. 
Метою створення порталу системи електронних державних послуг для громадян є підвищення ефективності надання державних послуг. Воно спрямоване на спрощення обробки цивільних справ та офіційних запитів і дозволяє отримати інформацію про те, як їх оформити. Прийнята форма дозволяє зібрати в одному місці справи (питання), що входять до компетенції різних адміністративних підрозділів і надати доступ до процедур цих послуг в Інтернеті. Щоб реалізація послуг була можлива та здійснювалася на відповідному рівні, необхідні громадські точки доступу в Інтернет, які виконують чотири основні функції:

- популяризації Інтернету, особливо серед людей, котрі не мають можливості використання комп’ютера та послуг, доступних через Інтернет;

- полегшення доступу до інформаційних та адміністративних послуг, пропонованих через Інтернет державною адміністрацією та пов'язаними з нею установами;

- популяризації вільного програмного забезпечення, що дозволяє використовувати комп'ютери й Інтернет людям із низькими доходами;

- доповнення та розширення спектру електронних послуг, які надаються державними установами, громадськими організаціями тощо.

Багато авторів звертають увагу на принципи та методологію побудови сайтів, їхній зміст, естетику; можна знайти цікаву інформацію про сайти для комерційних організацій, підприємств обраних секторів, установ; пропонуються різні методики тестування якості сайтів [2-4]. Зазвичай автори посібників займаються будівництвом порталів для бізнесу.

Специфіка системи електронних державних послуг така, що вже на законодавчому рівні викладені певні вимоги до структури та змісту державних сайтів, які надають електронні державні послуги для фізичних і юридичних осіб.

До основних завдань системи електронних державних послуг належать:

- координація й адміністрування взаємодії між державними структурами;

- організація обслуговування громадян державними органами;

- організація взаємодії структур влади та бізнесу;

- видача громадянам будь-якої інформації, пов'язаної з діяльністю державних органів;

- створення форм правління за участю громадян;

- забезпечення рівної доступності благ незалежно від місця проживання громадянина;

- забезпечення електронними державними послугами всього населення;

- забезпечення відстеження статусу документів, які посилаються у державні структури, що дозволяє дізнатися, на якому етапі реалізації він знаходиться;

- розширення спектру державних послуг, що надаються онлайн;

- реорганізація та реформування високозатратних державних структур влади;

- підвищення використання та якості інформації в обсязі всього суспільства;

- забезпечення системи електронних державних послуг механізмами для прозорості діяльності державних установ і процесів взаємодії з ними.

Діалог громадян із державними службовцями онлайн дозволить організувати взаємодію між ними цілодобово й у будь-який час.

Підприємствам необхідно надати доступ до електронних податкових та інших платежів, податковоїзвітності, реєстрації товарних знаків і патентів, до систем електронних державних закупівель, різних програм підтримки та розвитку бізнесу і т. п. Взаємодія з державними органами за допомогою ІКТ призводить до підвищення конкурентоспроможності компаній і зменшення витрат на документообіг [1, с. 62]. 
Портал системи електронних державних послуг може надавати різну інформацію: про місцеві події, як вирішити це питання і до кого звернутися, про вільні робочі місця і т. п., завдяки чому досягається орієнтований на потреби населення і справедливий підхід до надання державних електронних послуг. Структура онлайнової системи електронних державних послуг і їі органів управління повинна містити у собі:

- інтернет-загальнодоступні сервери, що надають доступ до електронних державних послуг;

- безкоштовні контакт-центри, суміщені 3 мережею телефонні call-центри, які дозволяють надавати послуги для громадян, котрі не мають доступу в Інтернет;

- поштову службу для посилки документів і матеріалів у письмовому вигляді;

- інтранет для підвищення ефективності роботи державних службовців.

Розвинені країни у плані відкритості й ефективності державного сектору та готовності здійснювати електронні послуги посідають перші місця за економічними показниками та конкурентоспроможністю. Це доказ того, що існує тісний зв'язок між конкурентоспроможністю, інноваційністю та якістю державного управління у різних країнах. Прискорення введення електронних послуг державної адміністрації має також важливе значення з погляду модернізації та інновацій, де влада змушена мати справу із серйозними проблемами, такими як старіння суспільства, зміна клімату і тероризм. Одночасно громадяни вимагають сучасних послуг, більш високого рівня безпеки та кращої демократії, а бізнес вимагає меншої бюрократії та більшої ефективності дії. У міру розширення Європейського Союзу, за одночасного підвищення його різноманітності 3'являються нові потреби в ефективному наданні державних транскордонних послуг для підвищення мобільності громадян і для потреб європейських підприємств. Електронні послуги державної адміністрації можуть допомогти урядам у вирішенні цих проблем і задоволенні потреб суспільства. Цільова концепція у країнах Європейського Союзу передбачає використання системи електронних послуг у різних країнах, а також реалізацію загальноєвропейських (пан'європейських) послуг. Реалізація цієї концепції знаходиться під постійним контролем Європейської Комісії через послідовне проведення досліджень рівня розвитку системи електронних державних послуг.

Обговорюючи електронні державні послуги, треба пам'ятати, що у соціально-економічній моделі Європейського Союзу публічна адміністрація відіграє особливу роль. Ї̈ї місія полягає у підтримці функціонування конкурентного ринку товариств Свропейського Союзу. Адміністрація спільноти безпосередньо бере участь у питаннях, що стосуються освіти, охорони здоров'я, соціального забезпечення, охорони навколишнього середовища та захисту прав споживачів.

Це, безумовно, відрізняє «європейську модель» електронного адміністрування від американської моделі, у якій федеральний уряд має дуже чітко визначену й обмежену владу [3, с. 55].

Для фізичних осіб у Свропейському Союзі вказані такі послуги, як:

1. Охорона здоров’я (реєстрація пацієнтів, вартість медичних послуг, електронний файл пацієнта з переліком захворювань і ліків і т. д.).

2. Соціальні допомоги (внески на фонди: пенсійний, охорони здоров'я, інвалідності, нещасних випадків; пенсії, соціальна допомога, медичне страхування і т. д.).

3. Видача дозволів на будівництво (дозвіл на будівництво будинку, приміщення для бізнесу, громадського користування і т. д.). 
4. Прийом віддалених заявок для поліції (повідомлення про сумні події, знищення державної власності, загрози життю, тероризм і т. д.).

5. Реєстрація транспортних засобів (реєстрація придбаних транспортних засобів, зняття транспортних засобів з обліку, видача водійських посвідчень тощо).

6. Видача документів, що засвідчують особу (тимчасове посвідчення особи, паспорт).

7. Пошук роботи (оголошення про роботу, курси для безробітних, реєстрація безробітних і т. д.).

8. Адресний стіл, зміна місця проживання (реєстрація постійного та тимчасового проживання, виїзд).

9. Бібліотеки, доступ до громадських ресурсів бібліотеки (бібліотечні ресурси, віддалений перегляд, замовлення обраних книг, журналів і т. д.),

10.РАЦС, видача актів про шлюб, народження, смерть і т. д.

11. Прибутковий податок із фізичних осіб (подача податкових декларацій, прийом змін у даних).

12.Реєстрація до вишу, прийом кандидатів на вищу освіту (заповнити та відправити заявку) [9, с. 14].

Для бізнесу (юридичних осіб) слід зазначити такі послуги, як:

1. Соціальне страхування (пенсійні внески, соціальне забезпечення, охорона здоров'я, пенсії, медичне страхування для співробітників; страхування від нещасних випадків, фонд роботи і т. д.).

2. Податки від фірм, прибуткові податки з юридичних осіб (подача податкових декларацій через Інтернет).

3. Податок на додану вартість (подача декларацій ПДВ та податкові платежі в Інтернеті).

4. Реєстрація бізнесу (заповнити та відправити заявку).

5. Ресурси статистики (передача даних у статистичне управління).

6. Митні декларації (заповнення та подання митних декларацій).

7. Дозволи та сертифікати охорони навколишнього середовища (заповнення та подання заяв через Інтернет).

8. Державні закупівлі (зацікавлені в аукціоні-конкурсі підприємства стежать за інформацією, оголошеннями на веб-сайтах) [5, с. 36].

Існує чотири рівні зрілості електронних державних послуг:

- інформаційний - офіси публікують інформацію на веб-сайті, а користувачі переглядають сайт офісів на комп’ютері або спеціальних інформаційних кіосках, отримуючи необхідну інформацію;

- інтерактивний, в одну сторону - користувачі можуть спілкуватися в електронному вигляді з окремими офісами, двосторонній - де офіси можуть спілкуватися $з$ користувачами через Інтернет;

- угоди - користувачі можуть спілкуватися в електронному вигляді з окремими офісами, а офісні додатки електронним шляхом їм відповідають;

- інтеграції - портали призначені для певних цілей, надають інформацію 3 різних офісів і дозволяють здійснювати виконання угод. Рівень інтеграції дозволяє виконувати дії, необхідні для вирішення офіційних питань (справ), в електронному вигляді: від отримання інформації, вибору відповідної форми, заповнення та відправлення її по мережі (можливість заповнення онлайн-форм на сайті), оплати необхідних зборів і до отримання офіційного паперу: дозвіл, Свідоцтво, рішення або інший документ, який заявник намагався отримати [6-8]. 
Нами досліджено етапи розвитку системи електронних державних послуг, цілі та завдання кожного етапу, проблеми та рекомендації щодо їх нівелювання.

Етап 1. Основна мета - забезпечення загального доступу до інформації про діяльність органів державної влади. Основні завдання: створення інформаційного порталу, що містить оперативну та довідкову інформацію про державну установу та прийняті ними рішення; підвищення комп'ютерної грамотності. Основні проблеми: проблема системності, стандартизації (комп'ютерні програми для порталів державних установ розробляють безліч фірм, котрі використовують різні мови програмування і несумісні між собою програмні рішення); слабо розвинені інформаційно-телекомунікаційні системи; проблема так званої цифрової нерівності (digital-divide). Шляхи вирішення: вибір єдиного генерального підрядника для країни (групи країн), який визначатиме загальні вимоги до програмного продукту, встановлення стандартів, визначення протоколів обміну інформацією; сприяння держави у розвитку ІКТ-систем (субсидії, податкові пільги і т. д.), стимулювання попиту на IКТ; створення спеціальних освітніх програм.

Етап 2. Основна мета - двосторонній обмін інформацією між органами влади та бізнесом або громадянами. Основні завдання: стандартизація процесу обміну даними; стандартизація процесів зберігання даних; розробка необхідних баз даних; введення ID-електронного підпису. Основні проблеми: проблема системності; проблема інформаційної безпеки. Шляхи вирішення: вибір єдиного генерального підрядника; розробка антивірусних програм; удосконалення адміністративного та кримінального законодавства, що регулює взаємодію в інформаційному просторі.

Етап 3. Основна мета - надання окремих державних послуг (наприклад, сплата податків). Основні завдання: надання першочергових державних послуг згідно із затвердженим списком; забезпечення інформаційної безпеки. Основні проблеми: проблема інформаційної безпеки; проблема зручності інтерфейсу як для користувачів, так і для державних службовців; проблема доступності та рівня зрілості електронних державних послуг. Шляхи вирішення: ергономіка інтерфейсу, в т. ч. дослідження якості сайту; аналіз доступності та рівня зрілості електронних державних послуг, розробка заходів щодо їх підвищення.

Етап 4. Основна мета - надання всього комплексу послуг для всіх споживачів через єдиний інформаційний портал. Основні завдання: створення єдиного інтегрованого інформаційного порталу; забезпечення сумісності різних порталів; розробка інструментів для легкого обслуговування інформаційного порталу людей зі слабким зором, інвалідністю; забезпечення безаварійної роботи порталу; розробка програм-провідників для вирішення таких послуг і зменшення цифрової нерівності; розробка системи пошуку спроб незаконного входу в систему. Основні проблеми: проблема інтероперабельності та стандартизації (несумісність програмного забезпечення); проблема доступності та рівня зрілості електронних державних послуг. Можливі два шляхи вирішення: 1) менш витратний на початковому етапі - розробники порталів розробляють протоколи обміну даними з інтегрованим порталом, які надалі повинні постійно підтримуватися; 2) правильний вибір єдиного генерального підрядника для країни (групи країн), котрий визначає загальні вимоги до програмного продукту, встановлює стандарти, протоколи обміну інформацією і т. д., а всі портали розробляються з «нуля».

Етап 5. Основна мета - система електронних державних послуг як частина інформаційного суспільства. Основні завдання: ефективний обмін інформацією та поліпшення якості послуг у галузі державного управління, бізнесу, освіти 
й охорони здоров'я, культури і т. д. Сценаріі: песимістичний - повне панування ІКТ у житті людини, всі додатки та бази даних будуть створені з урахуванням людської прихильності до комп'ютера і з метою отримання контролю над ним. Оптимістичний - соціальні мережі сприятимуть розвитку цивілізації та створенню кращих відносин між компаніями. Шляхи вирішення: забезпечення адміністратором порталу інформаційної безпеки.

Європейський Союз стимулює розвиток систем електронних державних послуг надання електронних державних послуг шляхом проведення досліджень їх доступності та рівня зрілості у країнах-членах ЄС.

Дослідження показали, що підприємці частіше, ніж фізичні особи (громадяни) вважають за краще користуватися онлайн-послугами. Велика зацікавленість із боку підприємців до електронних послуг є економічним підходом, який виникає у зв'язку з великою частотою реалізації таких послуг, оскільки підприємці, заплативши за сертифікат кваліфікованого електронного підпису, використовують його багаторазово на рік. Крім того, юридичні міркування припускають виконання послуг для підприємців на рівні трансакцій. У фізичних осіб спостерігається менший інтерес до сфери електронних послуг у зв'язку з високою вартістю сертифіката кваліфікованого електронного підпису, який буде використовуватися один або дуже малу кількість разів на рік. У деяких країнах $\mathrm{CC}$ проблема наявності сертифіката кваліфікованого електронного підпису була вирішена шляхом видачі посвідчення особи з ID. Серед послуг для фізичних осіб є послуги, що через юридичні обмеження не можуть бути поки реалізовані. Це послуги, пов'язані з видачею посвідчення особи, дозволу на будівництво та ін.

Висновки і пропозиції. Розвиток системи електронних державних послуг вигідний як для підприємств, так і для громадян, але насамперед самій державній адміністрації. Можливість використовувати дані в електронній версії дозволяє домогтися економії часу, пов'язаної з необмеженим тимчасово-просторовим доступом до будь-якої записаної інформації. Правильне використання інформаційних і комунікаційних технологій в офісах дозволить домогтися прозорості у діяльності органів державної адміністрації та зниження фінансових витрат і тягаря посадових осіб у роботі з клієнтами.

На початку XXI ст. ініціативи Комісії із систем електронних державних послуг орієнтувалися на розвиток електронних послуг (проекти, спрямовані на надання державних послуг онлайн). Нині ці проекти у більшості вже виконані, а установи прагнуть до наступного етапу розвитку інтелектуальних електронних послуг, орієнтованих на користувачів.

\section{СПИСОК ВИКОРИСТАНОӤ ЛІТЕРАТУРИ:}

1. Адміністративні послуги місцевих органів державної виконавчої влади : монографія / А.О. Чемерис, М.Д. Лесечко, А.В. Ліпенцев та ін. ; за заг. ред. А.О. Чемериса. Львів : ЛРІДУ НАДУ, 2004. 152 с.

2. Банасиковска Я. Интероперабельность в странах Европейского Союза и ее значение для решения электронных государственных услуг. Вестник НГУЭУ «Бизнес-информатика». 2014. № 3. С. 239-246.

3. Забара І. Правові аспекти співробітництва України з Європейським Союзом у розвитку інформаційного суспільства. Журнал європейського $і$ порівняльного права. 2016. Вип. 3. С. 28-42.

4. Карпенко О.В. Управлінські послуги в Україні: механізми надання органами влади : монографія. Київ : АМУ, 2014. 408 с. 
5. Клімушин П.С.Стратегії та механізми електронного урядування в інформаційному суспільстві : монографія. Харків : Вид-во ХарРІНАДУ «Магістр», 2016.524 с.

6. Лугачев М.И. Концепция и состояние реализации е-Администрации в Европейском Союзе. Актуальные проблемы экономики и права. 2021. № 4. С. 185-190.

7. Петрова М.М. Электронный менеджмент в публичном секторе Болгарии : монография. Белово : Faber, 2019. 330 с.

8. Розвиток партнерства між місцевою владою та недержавним сектором у сфері надання громадських послуг : монографія / О.В. Берданова, В.М. Вакуленко, М.Д. Василенко та ін. ; за заг. ред. Ю.П. Лебединського. Ужгород : Патент, 2003. 192 c.

9. Діяльність публічної адміністрації з надання послуг українському суспільству : монографія / В.М. Сороко, А.В. Вишневський, О.Г. Рогожин та ін.; за наук. ред. Ю.А. Привалова. Київ : Вид-во НАДУ, 2007. 180 с.

\section{REFERENCES:}

1. Chemerys, A.O., Lesechko, M.D., Lipentsev, A.V. (2004). Administratyvni posluhy mistsevykh orhaniv derzhavnoi vykonavchoi vlady [Administrative Services of local state executive authorities]. Lviv: LRIDU NADU, [in Ukrainian].

2. Banasikovska, Ya. (2014). Interoperabel'nost'v stranakh Evropeyskogo Soyuza i ee znachenie dlya resheniya elektronnykh gosudarstvennykh uslug. [Interoperability in the European Union and its importance for the solution of electronic public services]. Vestnik NGUEU "Biznes-informatika" - Bulletin of NGUEU "Business Informatics". 3. 239-246. [in Russian].

3. Zabara, I. (2016). Pravovi aspekty spivrobitnytstva Ukrainy z Yevropeiskym Soiuzom u rozvytku informatsiinoho suspilstva. [Legal aspects of Ukraine's cooperation with the European Union in the development of the information society]. Zhurnal yevropeiskoho i porivnialnoho prava - Journal of European and Comparative Law. 3. S. 28-42. [in Ukrainian]

4. Karpenko, O.V. (2014). Upravlinski posluhy v Ukraini: mekhanizmy nadannia orhanamy vlady [Management services in Ukraine: mechanisms for providing authorities]. Kyiv: AMU, [in Ukrainian].

5. Klimushyn, P.S. (2016). Stratehii ta mekhanizmy elektronnoho uriaduvannia v informatsiinomu suspilstvi [Strategies and mechanisms of e-government in the information society]. Kharkiv: Vyd-vo KharRI NADU "Mahistr", [in Ukrainian].

6. Lugachev, M.I. (2021). Kontseptsiya i sostoyanie realizatsii e-Administratsii v Evropeyskom Soyuze. [The concept and state of implementation of e-Government in the European Union]. Aktual'nye problemy ekonomiki i prava - Current issues of economics and law. 4. 185-190. [in Russian].

7. Petrova, M.M. (2019). Elektronnyy menedzhment v publichnom sektore Bolgarii [Electronic management in the public sector of Bulgaria]. Belovo: Faber, [in Russian].

8. Berdanova, O.V., Vakulenko, V.M., Vasylenko, M.D. (2003). Rozvytok partnerstva mizh mistsevoiu vladoiu ta nederzhavnym sektorom u sferi nadannia hromadskykh posluh [Development of partnership between local authorities and the non-state sector in the field of public services provision]. Uzhhorod : Patent, [in Ukrainian].

9. Soroko, V.M. Vyshnevskyi, A.V., Rohozhyn, O.H. (2007). Diialnist publichnoi administratsii $\mathrm{z}$ nadannia posluh ukrainskomu suspilstvu [Activities of public administration to provide services to Ukrainian society]. Kyiv: Vyd-vo NADU, [in Ukrainian]. 